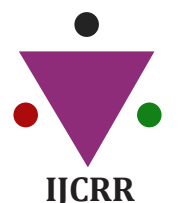

ection: Healthcare

Sci. Journal Impact

Factor: $6.1(2018)$

ICV: $90.90(2018)$

(c) (1) (9)

Copyright@IJCRR

\title{
Effectiveness of Turmeric (Curcuma longa Linn) Extract Gel (EG) on Wound Healing in Female Rats (Rattus Novergicus)
}

\author{
Arfiani Busman' ${ }^{1}$, Andi Nilawati Usman' ${ }^{1}$, Risfah Yulianty ${ }^{2}$, Mardiana Ahmad ${ }^{1}$, \\ Prihantono ${ }^{3}$, Latifah Rahman ${ }^{2}$, Andi Sumidarti ${ }^{4}$
}

'Department of Midwifery, Graduate School, Hasanuddin University, Indonesia; ${ }^{2}$ Faculty of Pharmacy, Hasanuddin University, Indonesia;

${ }^{3}$ Faculty of medicine, Hasanuddin University, Indonesia; ${ }^{4}$ Hasan Uddin University, Indonesia

\section{ABSTRACT}

Objective: The purpose of this study was to identify differences in wound healing and wound healing time at each concentration of turmeric extract gel (Curcuma longa Linn) and base gel on days 3, 7 and 14, and identify the most effective turmeric extract gel for wound healing in cuts female rats (Rattus Novergicus).

Method: This study was an experimental laboratory using a post-test only with a control group. This study used 16 female rats, 3 treatment groups, and 1 control group (each group consisted of 4 mice). Female rats were injured in the back section by slashing along $1.5 \mathrm{~cm}$ with a depth of $0.2 \mathrm{~cm}$. The treatment group was given turmeric extract gel with a concentration of $5 \%, 10 \%$, $15 \%$, and the control group was only given a gel base. This research was conducted for 14 days of topical turmeric extract gel by giving 2 times a day. The normality test uses the Shapiro Wilk test, then the Kruskal Wallis test, and continued with the PostHoc Mann-Whitney.

Results: The mean on the 3rd day of the EG group was $5 \%(0.95 \mathrm{~cm})$, the EG group was $10 \%(0.98 \mathrm{~cm})$, the group was $15 \%$ $(1.23 \mathrm{~cm})$, and the control group $(1.25 \mathrm{~cm})$. On the 7 th day EG 5\% $(0.58 \mathrm{~cm})$, EG $10 \%(0.65 \mathrm{~cm})$, EG $15 \%(0.73 \mathrm{~cm})$ and the control group $(1 \mathrm{~cm})$. On day 14 showed wound healing in the treatment group, but the control group showed mean wound length on day $14(0.15 \mathrm{~cm})$. Test results on day 3 obtained $p=0.007$, on day 7 obtained $p=0.010$ and on day 14 obtained $p$-value $=$ 0.017. $P$ values on days 3,7 , and 14 showed significant differences with $p<0.05$.

Conclusion: There are differences in wound healing and wound healing time at each concentration of turmeric extract gel. Turmeric extract gel concentration is the most effective healing wound cuts in female rats, namely the treatment group given EG $5 \%$.

Key Words: Turmeric extract, Gel, Female rat, Wound

\section{INTRODUCTION}

Women delivery may experience problems when labour takes place including rupture of the birth canal or perineum. More than $85 \%$ of vaginal deliveries will experience perineal trauma and nearly $69 \%$ require. ${ }^{1}$ The impact of perineal rupture on the mother such as infection of the bladder or on the birth canal. Bleeding can also occur due to the opening of blood vessels that do not close completely. Also, an increased risk of postpartum urinary retention, dyspareunia, and death can occur if treatment is slow. ${ }^{2-4}$

The World Health Organization (WHO) estimates that around three-quarters of the population of developing countries depend on traditional medicines (medicinal plants), for their primary health care needs. ${ }^{3}$ In Indonesia, the use of plants around the house has happened since a long time ago, but only a little has been proven scientifically, so it needs to be proven scientifically so that the utilization of these plants is increasingly apparent. The main part of turmeric is the rhizome which contains two secondary metabolites of phenolic curcuminoids and essential oils. The main curcuminoids found in turmeric are curcumin, demetoxy curcumin, and bisdemetoxycurcumin. ${ }^{4}$ Research on the initial phytochemical content of the ethanol extract of Curcuma longa Linn7 and other studies showing the presence of curcumin, essential oils, tannins, alkaloids, saponins, flavonoids, terpenoids which have important pharmacological activities such as anti-mutagenic, anti-inflammatory, antibacterial, antipro-

\section{Corresponding Author:}

Andi Nilawati Usman, Department of Midwifery, Graduate School, Hasanuddin University, Indonesia. E-mail: andinilawati@pasca.unhas.ac.id; nilawatiandi@gmail.com

ISSN: 2231-2196 (Print)

Received: 26.05 .2020
ISSN: 0975-5241 (Online)

Revised: 15.07 .2020
Accepted: 25.08 .2020

Published: 14.12 .2020 
tozoal, and properties antioxidant, and as an antiseptic, anticarcinogenic, anticoagulant, antifertility, antidiabetic, antifungal, antiviral, antifibrosis, antivenom, antiulcer, antiulcer, hypotensive, and hypocholesterolemia. ${ }^{5}$

Research using turmeric with topical administration in thirty rats for seven days there was no significant difference between the application of $5 \%$ curcumin and $0.9 \%$ Sodium Chloride in wound healing. ${ }^{6}$ Research that also discusses the preparation of turmeric in the form of a $10 \%$ turmeric extract ointment can accelerate the healing of female rats given for fourteen days. ${ }^{7}$ Another study that discussed Curcuma longa water extract which was applied topically provided an antiinflammatory effect by suppressing endotoxin-induced uveitis in mice to reduce TNF- $\alpha$ activity. ${ }^{8}$

Based on this, it is necessary to do basic research on the effectiveness of turmeric gel extract (Curcuma longa Linn) in female rats (Rattus Novergicus) before it is applied to postpartum perineal wounds in humans.

\section{MATERIALS AND METHODS}

\section{Research sites}

The study was conducted in February 2020 to March 2020 and has received an ethical approval recommendation with the protocol number UH19121102. The study was conducted in four different places according to the stage of the study conducted. At the stage of turmeric processing and extraction carried out in the Phytochemical Laboratory of the Faculty of Pharmacy Hasanuddin University, and gel making at the Pharmacy Laboratory of the Faculty of Pharmacy Hasanuddin University, the animal testing stage at the Animal Laboratory of the Faculty of Medicine Hasanuddin University.

\section{Materials}

Plastic boxes (with husks) and wire for rats cages, surgical equipment (anatomical scissors for surgery, scalpels, anatomical tweezers, scissors), plastics, analytical scales, filter paper, glass funnel, mortar, $100 \mathrm{ml}$ beaker glass, dropper, rotary evaporator, 75 gr plastic tube, cotton buds, gloves, tissue container, ruler, label, camera. The materials used in this study were, pet food (pallet), drinking water, Veet ${ }^{\circledR}$ cream, $70 \%$ ethanol, turmeric taken from Majene West Sulawesi Province, NaCMC, glycerin, propylene glycol, DMDM hydantoin, alcohol, aqua dest, ether, $70 \%$ alcohol, sterile gauze, sterile cotton.

\section{Research Design}

This research was a laboratory experimental method with experimental animals using a post-test with the control group.

\section{Population and Sample}

The population studied was female rats (Rattus Novergicus) Wistar strain. The number of samples used was sixteen rats consisting of four each group taken randomly. The inclusion criteria were female mice (Rattus Novergicus), aged 2-2.5 months, bodyweight 150-300 grams, healthy body condition (active and not disabled) with exclusion criteria, namely sick mice, body weight decreased to less than 150 grams, and died during the study.

\section{Procedure for the Making turmeric extract the gel}

Simplisia: Making simplicia from turmeric was done by collecting turmeric. Turmeric rhizome as much as 9 kilograms, then cleaned from attached by using flowing water then the sample is cut into small pieces, then dried by aerating it until it contains water content below $10 \%{ }^{9}$.

Simplisia Powder: Turmeric is ground until smooth and then sieved with a mesh size of 60 so that a smooth Simplicia sample of $500 \mathrm{gr}$ is obtained, after which the sample is ready for extraction of the maceration method.

Yellow Turmeric Rhizome Extract (Curcuma longa Linn): Turmeric powder (Curcuma longa Linn) is extracted by the maceration method (ie using $70 \%$ ethanol solvent). In the maceration process, the turmeric is soaked with $70 \%$ ethanol at room temperature for $3 \times 24$ hours, every $1 \times 24$ hours stirring. After $3 \times 24$ hours soaked, then filtered using filter paper, while macerated again. The extract obtained is then evaporated using a rotary evaporator until it thickens, the resulting viscous extract is put into a porcelain cup then dried with the help of a water bath ${ }^{10}$.

Making turmeric extract the gel: The extracted gel is made in 3 gel preparations, namely extracts with a concentration of 5; 10 ; and $15 \%$ (Table 1).

Table 1: Formulation of ingredients in the manufacture of turmeric extract gel

\begin{tabular}{lcccc} 
Material & \multicolumn{4}{c}{ Formula Composition (\% b/v) } \\
& F I & F II & F III & F IV \\
(Gel Base) & $($ EG 5\%) & $($ EG 10\%) & $($ EG 15\%) \\
Turmeric Extract & - & 5 & 10 & 15 \\
Alkohol & 5 & 5 & 5 & 5 \\
PG & 5 & 5 & 5 & 5 \\
Na. CMC & 5 & 5 & 5 & 5 \\
Gliserin & 5 & 5 & 5 & 5 \\
DMDM Hydan- & 0.1 & 0.1 & 0.1 & 0.1 \\
toin & 100 & 100 & 100 & 100 \\
Aquadest & & & & \\
\hline
\end{tabular}

PG: Propylene Glycol; Na. CMC: Natrium Carboxy Methyl Cellulose; DMDM: dimethyllimidazolidine.

The process of making a gel that is aquadest is heated to a temperature of $70^{\circ} \mathrm{C}$, then put a gel-forming (Na. CMC) into the mortar and added the aquadest that has been heated then crushed using a mortar until it develops to form a gel, 
add 5\% glycerin and 5\% propylene glycol, add DMDM Hydantoin $01 \%$ as a preservative, for turmeric extract a concentration of $5 \%$ is added to the gel that has been made then added to the alcohol everything is stirred until homogeneous, as well as for concentrations of $10 \%$ and $15 \%$.

\section{Animal Treatment}

Sixteen $(\mathrm{n}=16)$ rats were selected and weighed before treatment. Mice are adapted first by giving (pallet) and given drinking libitum, put in a cage with the same conditions for 1 week. Experimental animals were divided into 4 groups, each group consisting of 4 mice. The part of the back that will be wound, cleaned its bristles or applied a hair loss thresher (Veet ${ }^{\circledR}$ cream) on the part that will be made a wound. Do hand washing then use clean gloves, then coat the moustache on the rat to be hurt. Furthermore, rats were eliminated using ether by inhalation. The rat was injured on its back using a sterile scalpel $1.5 \mathrm{~cm}$ long and $0.2 \mathrm{~cm}$ deep. ${ }^{11}$

The control group, rats were only smeared with a gel base, and in three treatment groups, the wound was smeared with turmeric extract gel (Curcuma longa Linn) 2 times a day (7:00 am and 17:00) for 14 days. The application of the gel is done by using a sterile cotton bud to the wound. ${ }^{12}$

\section{RESULTS}

\section{Effect of gel on wound healing}

Data from this study were obtained from the results of the observation of wounds and determining the improvement of the wound healing process. One of them is done by measuring the length of the wound on days 3, 7, and 14 (Table 2). Table 2 shows the average wound length on day 0 of the treatment length of the wound length $1.5 \mathrm{~cm}$, on the $3 \mathrm{rd}$ day there was a rapid reduction in wound length in the EG group of 5\% (0.95 $\mathrm{cm})$, then the EG group $10 \%(0.98 \mathrm{~cm})$, and in the EG group $15 \%(1.23 \mathrm{~cm})$, and in the control group $(1.25 \mathrm{~cm})$. On the 7 th day the mean wound length was seen at EG $5 \%(0.58 \mathrm{~cm})$, EG $10 \%(0.65 \mathrm{~cm})$, then EG $15 \%(0.73 \mathrm{~cm})$, and lowest in the control group $(1 \mathrm{~cm})$. At the end of treatment on day 14 showed wound healing in all treatment groups of turmeric extract gel, but different from the control group which showed mean wound length on day $14(0.15 \mathrm{~cm})$ (Figure 1).

Table 2: Average length of incision wounds by treatment group

\begin{tabular}{lcccc}
$\begin{array}{l}\text { Treatment } \\
\text { group }\end{array}$ & \multicolumn{4}{c}{ Incision Length $(\mathrm{cm})$} \\
Day o & $\begin{array}{c}\text { Day o } \\
\text { averages } \\
\text { averages }\end{array}$ & $\begin{array}{c}\text { Day o } \\
\text { averages }\end{array}$ & $\begin{array}{c}\text { Day o } \\
\text { averages }\end{array}$ \\
Control & 1.5 & 1.25 & 1 & 0.15 \\
Extract Gel 5\% & 1.5 & 0.95 & 0.58 & 0 \\
Extract Gel 10\% & 1.5 & 0.98 & 0.65 & 0 \\
Extract Gel 15\% & 1.5 & 1.23 & 0.73 & 0 \\
\hline
\end{tabular}

Description: Extract Gel: Turmeric Extract

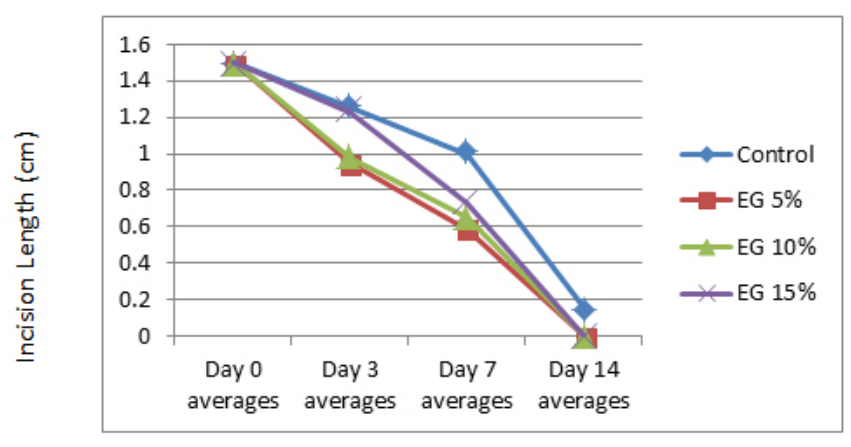

Figure 1: Graph of mean length of cut wounds of rats on days 3,7 and 14 .

Table 3 shows the results of the Kruskal Wallis test statistic on day 3 , the value of $\mathrm{P}=0.007$ was obtained, on the 7 th day $\mathrm{P}$-value $=0.01$ and on the 14 th day $\mathrm{P}$-value $=0.17$ was obtained. Because the P-value $<0.05$ there is a difference in wound length on the 3rd day, and the 7th, on the 14th day the value of $\mathrm{P}>0.05$, which means there is no difference in the length of the wound due to wound healing.

Table 3: Number of subjects per group, Median, minimum, and maximum of each group after giving turmeric extract gel, and P-value from Kruskal Wallis statistical results

\begin{tabular}{lcccc}
$\begin{array}{l}\text { Treatment } \\
\text { group }\end{array}$ & $\mathrm{N}$ & \multicolumn{3}{c}{ Incision Length $(\mathrm{cm})$} \\
Control & 4 & 3rd day & 7th day & 14th day \\
EG 5\% & 4 & $0.95(0.2-1.3)$ & 1 (o.8-1.2) & $0.15(\mathrm{o}-0.3)$ \\
EG 10\% & 4 & $0.95(0.9-1.1)$ & $0.65(0.6-0.6)$ & 0 \\
EG 15\% & 4 & $1.2(1.2-13)$ & $0.75(0.6-0.9)$ & 0 \\
P Value & & $\mathbf{0 . 0 0 7}$ & $\mathbf{0 . 0 1 0}$ & $\mathbf{0 . 0 1 7}$ \\
\hline
\end{tabular}

EG: Turmeric Extract

Table 4: Mann-Whitney Post Hoc Results

\begin{tabular}{|lcccccc}
$\begin{array}{l}\text { Treatment } \\
\text { group }\end{array}$ & \multicolumn{5}{c}{ Significance Test Results } \\
\hline 1 vs 2 & 3rd day & Sign & 7th day & Sign & 14th day & Sign \\
1 vS 3 & 0.018 & S & 0.017 & S & 0.047 & S \\
1 vS 4 & 0.495 & NS & 0.019 & S & 0.047 & S \\
2 vs 3 & 0.752 & NS & 0.096 & S & 0.047 & S \\
2 vs 4 & 0.017 & S & 0.044 & S & 1.000 & NS \\
| 3 vs 4 & 0.017 & S & 0.222 & NS & 1.000 & NS \\
& & &
\end{tabular}

$\mathrm{S}$ : significant, significantly different group $(\mathrm{P}<0.05)$; NS: NonSignificant, groups that were not significantly different $(\mathrm{P}>$ o.05); Group 1/control: gel base, 2: EG 5\%, 3: EG 10\%, 4: EG 15\%

Table 4 Mann Whitney Post Hoc Test Day 3 showed significant differences between treatment groups where group 1/ control (gel base) was significantly different from group 2 (EG 5\%), and group 3 (EG 10\%), but not significantly dif- 
ferent from the group 4 (EG 15\%), group 2 with group 3 were not significantly different, while group 2 with group 4 appeared to be significantly different, and group 3 appeared significantly different from group 4 . On day 7 showed group 1 was significantly different from group 2,3 , and 4 , group 2 showed no significant difference from group 3, but group 2 was significantly different from group 4 and group 3 and 4 showed no significant difference. On day 14 it appears that group 1 is significantly different from all groups 2, 3, and 4, group 2 shows no difference with groups 3 and 4, group 3 with 4 show no significantly different results (Table 5).

Table 5: Wound Healing Time after turmeric extract gel

\begin{tabular}{lc} 
Treatment group & Time of wound healing \\
Control & $>14$ days \\
EG $5 \%$ & $\leq 14$ days \\
EG $10 \%$ & $\leq 14$ days \\
EG $15 \%$ & $\leq 14$ days \\
\hline
\end{tabular}

EG: Turmeric Extract

Based on table 5 it can be seen that the wound healing time of all treatment groups containing turmeric extract when viewed at the end of the treatment ie on the 14th day experienced wound healing faster than the control group which only contained a gel base (Figure 2).

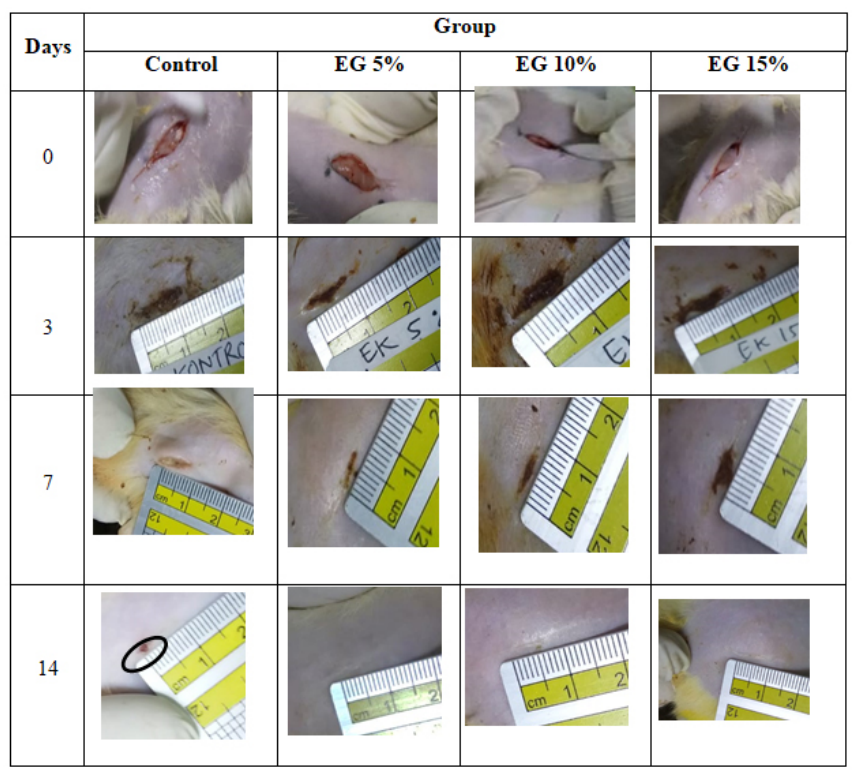

Figure 2: Wound healing activity.

\section{DISCUSSION}

The results of the measurement of wound length can be seen in Table 2 which shows that on the 3rd day there was a rapid shrinkage of the wound length in the EG group 5\% (0.95 $\mathrm{cm})$, then the EG group $10 \%(0.98 \mathrm{~cm})$, the group $15 \%(1.23$ $\mathrm{cm})$ and the lowest is in the control group $(1.25 \mathrm{~cm})$. On the 7 th day the mean wound length was seen at EG 5\% $(0.58$ $\mathrm{cm})$, EG $10 \%(0.65 \mathrm{~cm})$, then EG $15 \%(0.73 \mathrm{~cm})$, and lowest in the control group $(1 \mathrm{~cm})$. At the end of the treatment on the 14th day showed wound healing in all treatment groups containing turmeric (Curcuma longa Linn), but different from the control group which showed the average wound length on the 14th day $(0.15 \mathrm{~cm})$. This shows the shrinkage of the wound length is influenced by turmeric extract in the wound healing phase which consists of the inflammatory phase on the 3 rd day, on the 4th day to the 14th day is the proliferation phase and the maturation phase lasts up to 1 year or more. ${ }^{12-14}$

The results of this study found that turmeric extract gel with the smallest concentration of 5\% was effective against wound healing in mice. which showed similar results, where the concentration of turmeric rhizome ethanol extract gel which effectively healed the back skin of rabbits infected with Staphylococcus aureus ATCC 25923 was 5\%. This is in line with research conducted by Oktasiana, 2018 turmeric rhizome ethanol extract gel which effectively healed the back skin of rabbits infected with Staphylococcus aureus ATCC 25923 was $5 \% .^{10,11}$

Low concentrations are better than high concentrations because curcumin with high concentrations can increase the production of ROS (Reactive Oxygen Species) which produces oxidative stress so that it can inhibit the wound repair phase. ${ }^{14}$ ROS is also involved in wound healing, ROS acts as a signalling molecule and modulates cell growth, apoptosis, and differentiation. In low concentrations, ROS helps the signalling function. However, the presence of prolonged ROS at high concentrations produces oxidative stress, which can result in DNA damage. Oxidative stress is a factor that affects the wound healing process and generally inhibits tissue remodeling. ${ }^{15}$

The curcumin content of turmeric is believed to play an important role in the wound healing process. Curcumin can modulate physiological and molecular cells involved in inflammatory processes such as lymphocyte cells, monocytes, mast cells, neutrophils, and macrophages. Curcumin has antioxidant and anti-inflammatory properties to reduce the expression of inflammatory cytokines, shorten the inflammatory phase, and promote collagen synthesis, fibroblast migration, and differentiation ${ }^{16,17}$. Accelerating the wound healing process in this case turmeric extract gel inhibits the expression of proinflammatory cytokines such as interleukin (IL) $1,2,6,8$, and 12 , tumour necrosis factor-alpha (TNF- $\alpha$ ), suppress NF-kappaB and COX-2 activation, suppress Reactive Oxygen Science (ROS), monocyte chemoattractant protein (MCP). In the proliferation phase, curcumin helps collagen synthesis, fibroblast differentiation. This fibroblast will accelerate the synthesis of new skin tissue to accelerate 
wound closure. ${ }^{16,18}$ In the maturation or remodelling phase, curcumin increases type I collagen levels with the help of matrix metalloproteinase (MMP). ${ }^{19}$

Phenol compounds can denaturation bacterial cell proteins and damage bacterial cell membranes beyond repair. Saponins can increase pro-collagen synthesis, whereas tannins and flavonoids have antiseptic and antibacterial activity. Bioactive phytochemical compounds such as saponins, tannins, flavonoids can modulate one or more phases of the wound healing process. Besides, it is easily absorbed by superficial skin layers. ${ }^{20-22}$

\section{CONCLUSION}

In this study, it can be concluded that turmeric extract gel formula has effectiveness in healing cuts in female rats. The wound-healing effect when seen on the 14th day showed the same wound healing in all treatment groups with turmeric extract gel. The optimum wound healing effect of the wound when viewed from days 3,7 , and 14 is given by gel preparations with turmeric extract content of $5 \%$.

\section{ACKNOWLEDGMENT}

Authors acknowledge the immense help received from the scholars whose articles are cited and included in references to this manuscript. The authors are also grateful to authors / editors / publishers of all those articles, journals, and books from which the literature for this article has been reviewed and discussed.

\section{Conflict of Interest: Nil}

\section{Source of Funding: Nil}

\section{REFERENCE}

1. Astuti KEW, Handajani SR. Efektifitas Anti Inflamasi Formulasi Kunyit (Curcuma Longa), Daun Binahong (Anredera Cordifolia) Dan Daun Sambiloto (Andrographis Paniculata). Terhadap Luka Sayat Pada Kelinci 2018;223-6.

2. Goh R, Goh D, Ellepola H. Perineal tears - A review. Aust J Gen Pract 2018;47(1-2):35-8.

3. Joshi D, Kumar D, Shukla S, Kumar S, Dixit VA. Experimental and Toxicologic Pathology Curcuma longa Linn . extract and curcumin protect CYP 2E1 enzymatic activity against mercuric chloride-induced hepatotoxicity and oxidative stress : A protective approach. Exp Toxicol Pathol 2017;(2016):1-10.

4. Stanojević JS, Stanojević LP, Cvetković DJ, Danilović BR. Chemical Composition, Antioxidant And Antimicrobial Activity of the Turmeric Essential Oil (Curcuma Longa L .). AGRIS 2015;4(2):19-25.

5. Zhang Y, Mcclain SA, Lee H, Elburki MS, Yu H, Gu Y, et al. A Novel Chemically Modified Curcumin ( Normalizes ) WoundHealing in Rats with Experimentally Induced Type I Diabetes :
Initial Studies. J Diab Res 2016;2016: 5782904.

6. Sjahruddin AD, Irawananwar A, Tabri F, Djawad K, Daud D, Alam G. The Effect of Curcumin on the Acute Wound Healing of Mice. Am J Clin Exp Med 2015;3(4):189-93.

7. Milasari M, Jamaluddin AW, Adikurniawan YM. Pengaruh Pemberian Salep Ekstrak Kunyit Kuning (Curcuma Longa Linn) Terhadap Penyembuhan Luka Sayat Pada Tikus Putih (Rattus Norvegicus). J Ilm Ibnu Sina 2019;8(2):2019.

8. Agarwal R, Agarwal P, Srivastava S, Commission IP. Topically applied standardized aqueous extract of Curcuma longa Linn . suppresses endotoxin-induced uveal inflammation in rats. Indian J Exp Biol 2013 Oct;51(10):797-803.

9. Cobra LS, Amini HW, Putri AE. Skirining Fitokimia Ekstrak Sokhletasi Rimpang Kunyit ( Curcuma longa ) dengan Pelarut Etanol 96 \%. J Ilmiah Kesehatan Karya Putra Bangsa 2017;1(1):12-7.

10. Nurcholis W. Profil Metabolit Dan Bioaktivitas Beberapa Aksesi Temu Ireng ( Curcuma Aeruginosa Roxb.). J Agron Indonesia 2018; 44 (3) : 315 - 321.

11. Quave CL. Wound healing with botanicals: A review and future perspectives. Curr Dermatol Rep. 2018 Dec; 7(4): 287-295.

12. Ananto FJ, Herwanto ES, Nugrahandhini NB, Chizma Y. Gel Daun Kelor Sebagai Antibiotik Alami Pada Pseudomonas aeruginosa Secara In Vivo. J Pharmacy 2015;12:47-58.

13. Oktasiana AR. Uji Aktivitas Antibakteri Gel Ekstrak Rimpang Kunyit (Curcuma domestica Val.) Terhadap Bakteri Staphylococcus aureus ATCC 25923 Secara In Vivo. Berk Ilm Kedokt Duta Wacana. Farmaka 2018; 14(1):175-183.

14. Akbik D, Ghadiri M, Chrzanowski W, Rohanizadeh R. Curcumin as a wound-healing agent. Life Sci 2014;7.

15. Thangapazham RL, Sharad S, Maheswari RK. Review Article Skin Regenerative Potentials of Curcumin. BioFactors 2013;141-9.

16. Alawdi S. Formulation of Herbal Gel Preparations from Medicinal Plants and Evaluation of the Wound Healing Activities of their Wound Healing Activities. Saudi J Biol Sci 2019;4(8):279284.

17. Yue GGL, Chan BCL, Hon P, Lee MYH, Fung K, Leung P, et al. Evaluation of in vitro anti-proliferative and immunomodulatory activities of compounds isolated from Curcuma longa. Food Chem Toxicol 2020;48(8-9):2011-2020.

18. Bagad AS, Joseph JA, Bhaskaran N, Agarwal A. Comparative Evaluation of Anti-Inflammatory Activity of Curcuminoids, Turmerones, and Aqueous Extract of Curcuma longa. Adv Pharmacol Sci 2013;2013:7.

19. Bhagavathula N, Warner RL, Dasilva M, Mcclintock SD, Barron A, Aslam $\mathrm{MN}$, et al. A combination of curcumin and ginger extract improves abrasion wound healing in corticosteroid-impaired hairless rat skin. Wound Repair Regen 2009;32-4.

20. Ibrahim NI, Wong SK, Mohamed IN, Mohamed N, Chin KY, Ima-Nirwana $\mathrm{S}$, et al. Wound Healing Properties of Selected Natural Products. Int J Environ Res Public Health 2018 Nov; 15(11): 2360.

21. Kumara INC, Agung IG, Pradnyani S, Ayu IG, Novianthi F. Uji Efektivitas Ekstrak Kunyit (Curcuma longa) Terhadap Daya Hambat Pertumbuhan Bakteri Streptococcus Mutans. Intisari Sains Medis 2019;10(3):462-7.

22. Raorane CJ, Lee J, Kim Y, Rajasekharan SK, García-contreras $\mathrm{R}$, Lee J, et al. Antibiofilm and Antivirulence Efficacies of Flavonoids and Curcumin Against Acinetobacter baumannii. Front Microbiol 2019;10:1-12. 